\title{
Net energy levels on the lipid profile of pork
}

\author{
Stephan Alexander da Silva Alencar ${ }^{1}$ Charles Kiefer $^{1 *}$ Karina Márcia Ribeiro de Souza Nascimento ${ }^{1}$ \\ Luiz Henrique Viana ${ }^{1}$ Liliane Maria Piano Gonçalves ${ }^{1}$ Gabriel Cipriano Rocha ${ }^{2}$ \\ Anderson Corassa ${ }^{3}$ Alexandre Pereira dos Santos ${ }^{1}$
}

${ }^{1}$ Universidade Federal de Mato Grosso do Sul (UFMS), 79070-900, Campo Grande, MS, Brasil. E-mail: charles.kiefer@ufms.br. "Corresponding author. ${ }^{2}$ Universidade Federal de Viçosa (UFV), Viçosa, MG, Brasil.

${ }^{3}$ Universidade Federal de Mato Grosso (UFMT), Sinop, MT, Brasil.

ABSTRACT: This study was conducted to evaluate the effects of net energy levels on the lipid profile of adipose tissue and muscle of swines. A total of 90 animals, with initial weight of $71.94 \pm 4.43 \mathrm{~kg}$, were used, and distributed in a randomized block design in five net energy levels $\left(2,300,2,425,2,550,2,675\right.$, and 2,800 Kcal $\mathrm{kg}^{-1}$ feed $)$, with nine replicates and two animals per experimental unit. Lipid profiles of adipose tissue and muscle were analyzed using gas chromatography. Increasing the levels of net energy using soybean oil, improved the lipid profile of adipose tissue and muscle, increased linearly $(P<0.05)$ the concentrations of polyunsaturated fatty acids, especially linoleic and $\alpha$-linolenic acid, reduced linearly $(P<0.05)$ the monounsaturated and saturated fatty acids and omega 6: omega 3. In adipose tissue was observed linear reduction $(P<0.05)$ of atherogenic and thrombogenic indexes. In conclusion, increasing the level of net energy of the diet using soybean oil improved the lipid profile of adipose tissue and muscle.

Key words: atherogenic index, fatty acids, omega 3, omega 6, thrombogenic index.

Níveis de energia líquida no perfil lipídico da carne suína

RESUMO: Este estudo foi conduzido com o objetivo de avaliar o efeito dos níveis de energia líquida no perfil lipídico da gordura e carne

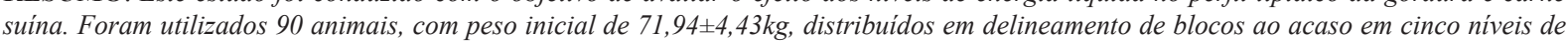
energia líquida (2.300, 2.425, 2.550, 2.675 e 2.800Kcal $\mathrm{kg}^{-1}$ de ração), com nove repetições e dois animais por unidade experimental. Foram analisados os perfis lipídicos da gordura subcutânea e da carne por cromatografia gasosa. O aumento do nível de energia líquida usando óleo de soja melhorou o perfil lipídico da gordura subcutânea e da carne, aumentando linearmente $(P<0,05)$ a concentração dos ácidos graxos poli-insaturados, especialmente ácido linoleico e $\alpha$-linolênico, reduzindo linearmente $(P<0,05)$ os ácidos graxos monoinsaturados e saturados e ômega 6: ômega 3. No tecido adiposo foi observado redução linear $(P<0,05)$ dos índices aterogênico e trombogênico. Em conclusão, o aumento do nível de energia líquida da dieta, com a utilização do óleo de soja, melhora o perfil lipidico da gordura subcutânea e da carne suína.

Palavras-chave: ácidos graxos, índice aterogênico, indice trombogênico, ômega 3, ômega 6.

\section{INTRODUCTION}

Fatty acid profile of pig carcasses can be modified by diet manipulation (DURAN-MONTGÉ et al., 2010). Thus, it is possible to manipulate the diets in order to improve the profile of fatty acids deposited in animal tissues, to obtain meat products better for consumer health (JAKOBSEN et al., 2009).

Lipid sources can be used to modify the energy value of feed, with the aim to achieve adequate net energy (NE) supply, which is the most accurate way of considering energy for formulation (NOBLET, 2007). Additionally, these sources can modify the lipid profile of deposited fat in pork, depending on the different concentrations of fatty acids.
The addition of oils in swine diet has been associated with a reduction of saturated fatty acids and an increase in polyunsaturated fatty acids in the deposited fat (KIM et al., 2014). The reduction of the saturated fatty acids, in particular lauric acid, myristic acid and palmitic acid is important, considering that they are involved in some pathologies (ULBRICHT \& SOUTHGATE, 1991), whereas the increase of polyunsaturated fatty acids are related to healthier products (JAKOBSEN et al., 2009).

However, this effect of oils will also depend on the source used, how long the diet is supplemented with oils and the concentration. Although, it is known that soybean oil increases C18:2n6 in fat (AVERETTEGATLIN et al., 2002), the effect of different levels of 
net energy using soybean oil on the lipid profile of adipose tissue and muscle remain unclear.

Therefore, this study was carried out with the aim to evaluate the effects of net energy levels using soybean oil on the lipid profile and assessing the atherogenic and thrombogenic indexes, as well as the omega 6:omega 3 ratio in adipose tissue and Longissimus dorsi muscle of pigs.

\section{MATERIALS AND METHODS}

A total of 90 genetically similar barrows, with an initial weight of $71.94 \pm 4.43 \mathrm{~kg}$ and final weight of $96.94 \pm 6.30 \mathrm{~kg}$, were used. Animals were distributed in a randomized block design according to their initial weight, in five net energy levels $(2,300,2,425,2,550$, 2,675 , and $2,800 \mathrm{Kcal} \mathrm{kg}^{-1}$ feed), with nine replications, where each experimental unit consisted of two animals.
The animals were housed in pens provided with semiautomatic feeders and bell drinkers, in a masonry shed, covered with ceramic tiles.

The experimental diets (Table 1) were prepared based on corn and soybean meal to meet the nutritional requirements of barrows with high genetic potential, as established by ROSTAGNO et al. (2011), except for the levels of metabolizable energy. Different levels of NE were obtained by the addition of soybean oil, replaced by kaolin in the original diet. The feed and water were provided $a d$ libitum throughout the experimental period, which lasted 30 days.

At the end of the experimental period, the animals were subjected to eight hours of fasting and were then transported to the abattoir. At the end of the slaughter line and before carcass cooling, samples were taken from the Longissimus dorsi

Table 1 - Nutritional and centesimal composition of experimental diets.

\begin{tabular}{|c|c|c|c|c|c|}
\hline \multirow{2}{*}{ Ingredient } & \multicolumn{5}{|c|}{ 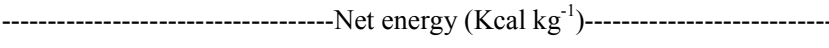 } \\
\hline & 2,300 & 2,425 & 2,550 & 2,675 & 2,800 \\
\hline Corn & 70.150 & 70.150 & 70.150 & 70.150 & 70.150 \\
\hline Soybean meal (45\%) & 20.444 & 20.444 & 20.444 & 20.444 & 20.444 \\
\hline Soybean oil & 0.000 & 1.697 & 3.394 & 5.091 & 6.790 \\
\hline Inert matter (kaolin) & 6.900 & 5.203 & 3.506 & 1.809 & 0.110 \\
\hline Dicalcium phosphate & 0.832 & 0.832 & 0.832 & 0.832 & 0.832 \\
\hline Limestone & 0.445 & 0.445 & 0.445 & 0.445 & 0.445 \\
\hline Vit. and min. supplement ${ }^{1}$ & 0.100 & 0.100 & 0.100 & 0.100 & 0.100 \\
\hline Sodium chloride & 0.305 & 0.305 & 0.305 & 0.305 & 0.305 \\
\hline L-Lysine $\mathrm{HCl}$ & 0.451 & 0.451 & 0.451 & 0.451 & 0.451 \\
\hline DL-Methionine & 0.159 & 0.159 & 0.159 & 0.159 & 0.159 \\
\hline L-Threonine & 0.177 & 0.177 & 0.177 & 0.177 & 0.177 \\
\hline L-Tryptophan & 0.037 & 0.037 & 0.037 & 0.037 & 0.037 \\
\hline \multicolumn{6}{|c|}{ - } \\
\hline Crude protein $(\%)$ & 16.00 & 16.00 & 16.00 & 16.00 & 16.00 \\
\hline $\mathrm{NE}\left(\mathrm{Kcal} \mathrm{kg}^{-1}\right)$ & 2,300 & 2,425 & 2,550 & 2,675 & 2,800 \\
\hline $\operatorname{ME}\left(\mathrm{Kcal} \mathrm{kg}^{-1}\right)$ & 3,045 & 3,186 & 3,327 & 3,468 & 3,608 \\
\hline Ether extract & 2.906 & 4.596 & 6.286 & 7.977 & 9.669 \\
\hline Digestible lysine (\%) & 1.000 & 1.000 & 1.000 & 1.000 & 1.000 \\
\hline Digestible met. + cyst. (\%) & 0.617 & 0.617 & 0.617 & 0.617 & 0.617 \\
\hline Digestible threonine (\%) & 0.667 & 0.667 & 0.667 & 0.667 & 0.667 \\
\hline Digestible tryptophan (\%) & 0.187 & 0.187 & 0.187 & 0.187 & 0.187 \\
\hline Digestible valine (\%) & 0.638 & 0.638 & 0.638 & 0.638 & 0.638 \\
\hline Calcium (\%) & 0.484 & 0.484 & 0.484 & 0.484 & 0.484 \\
\hline Available phosphorus (\%) & 0.248 & 0.248 & 0.248 & 0.248 & 0.248 \\
\hline Sodium (\%) & 0.160 & 0.160 & 0.160 & 0.160 & 0.160 \\
\hline
\end{tabular}

${ }^{1}$ Quantity per kilogram of diet: vitamin $\mathrm{A}-1,250 \mathrm{IU}$; vitamin $\mathrm{D}_{3}-250 \mathrm{IU}$; vitamin $\mathrm{E}-6.25 \mathrm{IU}$; vitamin $\mathrm{K}_{3}-0.75 \mathrm{mg}$; vitamin $\mathrm{B}_{1}-$ $0.375 \mathrm{mg}$; vitamin $\mathrm{B}_{2}$ - 1mg; vitamin $\mathrm{B}_{6}-0.375 \mathrm{mg}$; vitamin $\mathrm{B}_{12}-4.5 \mathrm{mcg}$; niacina - 4.5mg; pantothenic acid - 2.3mg; folic acid $0.0125 \mathrm{mg}$; iron - 25g; copper - 3.75mg; manganese - $12.5 \mathrm{mg}$; zinc $-31.25 \mathrm{mg}$; iodine $-0.25 \mathrm{mg}$; selenium - 0.075mg; excipient q.s.p. $1000 \mathrm{~g}$. 
muscle, with adipose tissue at the point P2 (region of insertion of the last thoracic vertebra with the first lumbar, at six centimeters from the dorsal line). Samples were obtained from animals of the study from GONÇALVES et al. (2015), identified, packaged and frozen for subsequent analysis.

The technique used for extracting lipids and methylation of fatty acids was adapted from methods published by HARA \& RADIN (1978). After thawing, $5 \mathrm{~g}$ of muscle tissue sample or $1.5 \mathrm{~g}$ of adipose tissue was added to test tubes. Then, a mixture of isopropanol/hexane was added to the test tube to extract the fatty acids from the samples, and a mixture of extracted and dried lipids was obtained from the process. Approximately 40mg of sample was then used to methylate these fatty acids. The weighed samples were placed in a test tube to which the solvents (methyl acetate, sodium methoxide-30\% methanol) and anhydrous oxalic acid solution were added.

Fatty acids were separated and identified by gas chromatography using gas-liquid chromatograph VarianCP-3800 with flame ionization detector(FID) and a "split/splitless" injector, in fused silica capillary column $30 \mathrm{~m}$ in length, $0.25 \mathrm{~mm}$ diameter with BPX70 (70\% Cyanopropylpolysilphenyl-siloxane).

The operating parameters were fixed at $250^{\circ} \mathrm{C}$ in the detector and $200^{\circ} \mathrm{C}$ in the injector. The initial column temperature was $80^{\circ} \mathrm{C}(2 \mathrm{~min})$, raising gradually to $220^{\circ} \mathrm{C}(10 \mathrm{~min})$ at $4^{\circ} \mathrm{C} \mathrm{min}^{-1}$. The carrier gas used was helium with a column flow of $1.0 \mathrm{ml} \mathrm{min}^{-}$ ${ }^{1}$; synthetic air and hydrogen were used as a gas for the detector, and nitrogen as "makeup" gas. For injection, $1 \mu \mathrm{L}$ was used. Identification and quantification of fatty acids were performed by means of retention time, comparison of the retention time (rt), and coinjection of methyl esters of fatty acids from samples and defaults (FAME mix, 100mg - 37 components). Quantification was achieved by expressing the values as percentage of total fatty acids identified.

The quality of the fatty acids of adipose tissue and muscle were assessed following the equation suggested by ULBRICHT \& SOUTHGATE (1991) for $\mathrm{AI}$ and TI: $\mathrm{AI}=\mathrm{C} 12: 0+(4 \times \mathrm{C} 14: 0)+\mathrm{C} 16: 0 /($ Omega $6)+($ Omega 3$)+$ MUFA; TI $=$ C14:0 $+\mathrm{C} 16: 0+\mathrm{C} 18: 0 /$ $(0.5 \times \mathrm{C} 18: 1)+(0.5 \times$ MUFA $)+(0.5 \times$ Omega 6$)+(3 \times$ Omega 3) + (Omega 3: Omega 6).

The data obtained were submitted to an analysis of variance with the GLM procedure in the statistical software SAS (Statistical Analysis System University Edition). The following model was used: $\mathrm{Y}_{\mathrm{ij}}=\mu+\mathrm{E}_{\mathrm{i}}+\mathrm{B}_{\mathrm{j}}+\mathrm{e}_{\mathrm{ij}}$, where, $\mathrm{Y}_{\mathrm{ij}}=$ estimate of the average of the study variables, $\mu=$ overall average, $E_{i}=$ effect of the $i^{\text {th }}$ level of NE, $\mathrm{B}_{\mathrm{j}}=$ effect of the $\mathrm{j}^{\text {th }}$ block, and $\mathrm{e}_{\mathrm{i} j}$
$=$ random error associated with observation $\mathrm{Y}_{\mathrm{ij}}$. When a significant difference was observed, the analysis of linear and quadratic regression was carried out. The significance level adopted was of 5\%.

\section{RESULTS}

Net energy levels influenced $(\mathrm{P}<0.05)$ the lipid profile of adipose tissue, where a linear reduction of fatty acids myristic, palmitic, palmitoleic, stearic, oleic and $\gamma$-linolenic acid was observed, with increased levels of NE in the diet (Table 2). Conversely, a linear increase of polyunsaturated fatty acids (PUFA) linoleic, $\alpha$-linolenic, and eicosatrienoic acid, was observed with an increase of NE levels in the diet.

Lipid profile of muscle was altered by $\mathrm{NE}$ levels, where there was a linear decrease $(\mathrm{P}<0.05)$ of the fatty acids palmitoleic, stearic, oleic and $\gamma$-linolenic acid with increasing levels of NE. The PUFA linoleic, $\alpha$-linolenic and arachidonic acid increased $(\mathrm{P}<0.05)$ as NE levels in the diet increased.

The NE of the diet changed the concentration of total fatty acids in the adipose tissue and muscle, where the increase in the level of $\mathrm{NE}$ resulted in a reduction $(\mathrm{P}<0.05)$ of saturated fatty acids (SFA) and monounsaturated fatty acids (MUFA). Consequently, the unsaturated fatty acids (UFA) and PUFA increased $(\mathrm{P}<0.05)$, as also the omega 6: omega $3(\mathrm{P}<0.05)$. The AI and TI of the adipose tissue decreased $(\mathrm{P}<0.05)$, following the increase in the level of NE in the diet. Regression equations obtained for the variables analyzed in the adipose tissue and muscle, with regard to the levels of NE, are shown in table 3.

\section{DISCUSSION}

In the previous trial (GONÇALVES et al., 2015) from which the performance of the animals was assessed and subsequently the samples were collected for the present study, the increase of net energy levels reduced daily feed intake and improved feed:gain ratio; and albeit, no effect on daily net energy intake was observed, the range of soybean oil concentrations from the diets were enough to alter lipid profile.

Ingestion of linoleic acid is linearly related to the amount of this fatty acid reported in carcass fat (AVERETTE-GATLIN et al., 2002). This leads us to infer that the fatty acid profile of pork fat is affected by diet composition, an observation corroborated by other researchers (KOUBA \& MOUROT, 2011; KIM et al., 2014). In this study, the increase of PUFA, especially 
Table 2 - Lipid profile (\%), atherogenic and thrombogenic indexes and omega 6: omega 3 ratio of adipose tissue and Longissimus dorsi muscle from pigs fed with different net energy levels.

\begin{tabular}{|c|c|c|c|c|c|c|c|}
\hline \multirow{2}{*}{ Lipid Profile } & \multicolumn{5}{|c|}{-----------Net energy $\left(\mathrm{Kcal} \mathrm{kg}^{-1}\right)$---------- } & \multirow{2}{*}{ SEM $^{*}$} & \multirow{2}{*}{ P-value ${ }^{1}$} \\
\hline & 2,300 & 2,425 & 2,550 & 2,675 & 2,800 & & \\
\hline \multicolumn{8}{|c|}{ 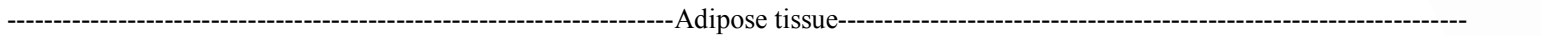 } \\
\hline C12:0 (Lauric acid) & 0.08 & 0.08 & 0.08 & 0.08 & 0.08 & $<0,01$ & 0.390 \\
\hline C14:0 (Myristic acid) & 1.36 & 1.32 & 1.33 & 1.26 & 1.23 & 0.04 & 0.006 \\
\hline C16:0 (Palmitic acid) & 24.42 & 23.31 & 24.10 & 22.70 & 21.66 & 0.40 & 0.001 \\
\hline C16:1 (Palmitoleic acid) & 2.19 & 2.05 & 1.91 & 1.86 & 1.75 & 0.09 & 0.001 \\
\hline C18:0 (Stearic acid) & 10.92 & 10.49 & 11.23 & 10.15 & 9.72 & 0.33 & 0.001 \\
\hline C18:1n9 (Oleic acid) & 41.45 & 40.53 & 38.58 & 38.91 & 37.63 & 0.58 & 0.001 \\
\hline C18:2n6 (Linoleic acid) & 14.81 & 17.39 & 18.13 & 19.78 & 22.60 & 0.76 & 0.001 \\
\hline C18:3n6( $\gamma$-Linolenic acid $)$ & 0.16 & 0.15 & 0.13 & 0.13 & 0.13 & $<0.01$ & 0.010 \\
\hline $\mathrm{C} 18: 3 \mathrm{n} 3$ ( $\alpha$-Linolenic acid) & 0.61 & 0.82 & 0.92 & 1.12 & 1.32 & 0.05 & 0.001 \\
\hline C20:3n6(Dihomo- $\gamma$-Linolenic acid) & 0.10 & 0.11 & 0.10 & 0.11 & 0.11 & $<0.01$ & 0.347 \\
\hline C20:4n6 (Arachidonic acid) & 0.24 & 0.26 & 0.24 & 0.25 & 0.28 & 0.01 & 0.151 \\
\hline C20:3n3 (Eicosatrienoic acid) & 0.10 & 0.12 & 0.12 & 0.14 & 0.14 & $<0.01$ & 0.001 \\
\hline C20:5n3 (Eicosapentaenoic acid) & 0.02 & 0.01 & 0.01 & 0.02 & 0.02 & $<0.01$ & 0.372 \\
\hline C22:6n3 (Docosahexaenoic acid) & 0.02 & 0.02 & 0.02 & 0.02 & 0.02 & $<0.01$ & 0.354 \\
\hline Saturated fatty acids & 38.59 & 37.03 & 38.29 & 36.13 & 34.44 & 0.52 & 0.001 \\
\hline Unsaturated fatty acids & 61.41 & 62.97 & 61.71 & 63.87 & 65.56 & 0.60 & 0.001 \\
\hline Monounsaturated fatty acids & 45.13 & 44.02 & 41.77 & 42.08 & 40.58 & 0.63 & 0.001 \\
\hline Polyunsaturated fatty acids & 16.28 & 18.95 & 19.73 & 21.79 & 24.97 & 0.84 & 0.001 \\
\hline Atherogenic index & 0.49 & 0.46 & 0.48 & 0.44 & 0.41 & 0.01 & 0.001 \\
\hline Thrombogenic index & 1.20 & 1.12 & 1.18 & 1.07 & 1.00 & 0.03 & 0.001 \\
\hline Omega 6: omega 3 & 21.13 & 18.62 & 17.58 & 15.99 & 15.86 & 0.43 & 0.001 \\
\hline \multicolumn{8}{|c|}{----c-} \\
\hline C12:0 (Lauric acid) & 0.09 & 0.09 & 0.10 & 0.09 & 0.10 & $<0.01$ & 0.073 \\
\hline C14:0 (Myristic acid) & 1.42 & 1.41 & 1.50 & 1.43 & 1.49 & 0.04 & 0.353 \\
\hline C16:0 (Palmitic acid) & 26.09 & 25.43 & 25.32 & 25.65 & 25.20 & 0.42 & 0.539 \\
\hline C16:1 (Palmitoleic acid) & 3.32 & 3.16 & 3.11 & 3.04 & 2.78 & 0.12 & 0.033 \\
\hline C18:0 (Stearic acid) & 12.20 & 11.95 & 11.60 & 11.31 & 10.90 & 0.29 & 0.018 \\
\hline C18:1n9 (Oleic acid) & 44.14 & 43.08 & 43.58 & 43.97 & 41.56 & 0.58 & 0.011 \\
\hline C18:2n6 (Linoleic acid) & 9.82 & 11.54 & 11.12 & 11.18 & 14.11 & 0.71 & 0.001 \\
\hline C18:3n6( $\gamma$-Linolenic acid $)$ & 0.14 & 0.14 & 0.13 & 0.11 & 0.11 & 0.01 & 0.027 \\
\hline C18:3n3 ( $\alpha$-Linolenic acid) & 0.32 & 0.50 & 0.49 & 0.52 & 0.66 & 0.03 & 0.001 \\
\hline C20:3n6 (Dihomo- $\gamma$-Linolenic acid) & 0.16 & 0.17 & 0.16 & 0.13 & 0.17 & 0.02 & 0.502 \\
\hline C20:4n6 (Arachidonic acid) & 0.04 & 0.06 & 0.06 & 0.07 & 0.08 & $<0.01$ & 0.001 \\
\hline C20:3n3 (Eicosatrienoic acid) & 0.01 & 0.01 & 0.01 & 0.01 & 0.02 & $<0.01$ & 0.201 \\
\hline C20:5n3 (Eicosapentaenoic acid) & 0.02 & 0.02 & 0.03 & 0.02 & 0.03 & $<0.01$ & 0.882 \\
\hline C22:6n3 (Docosahexaenoic acid) & 0.03 & 0.04 & 0.04 & 0.02 & 0.05 & $<0.01$ & 0.225 \\
\hline Saturated fatty acids & 41.00 & 40.15 & 39.58 & 39.59 & 38.80 & 0.51 & 0.049 \\
\hline Unsaturated fatty acids & 59.00 & 59.85 & 60.42 & 60.41 & 61.20 & 0.51 & 0.049 \\
\hline Monounsaturated fatty acids & 48.25 & 47.25 & 48.15 & 48.23 & 45.57 & 0.70 & 0.021 \\
\hline Polyunsaturated fatty acids & 10.80 & 12.59 & 12.15 & 12.18 & 15.33 & 0.76 & 0.001 \\
\hline Atherogenic index & 0.54 & 0.52 & 0.52 & 0.52 & 0.51 & 0.01 & 0.601 \\
\hline Thrombogenic index & 1.34 & 1.29 & 1.28 & 1.27 & 1.24 & 0.03 & 0.100 \\
\hline Omega 6: omega 3 & 25.05 & 23.54 & 20.88 & 20.18 & 19.62 & 0.81 & 0.001 \\
\hline
\end{tabular}

${ }^{*}$ Standard error mean. ${ }^{1}$ Linear effect $(\mathrm{P}<0.05)$.

1 linoleic acid, provided by diets with higher levels of

2 NE, was due to the use of soybean oil, which has a high concentration of linoleic fatty acids (ZAMBIAZI 1 et al., 2007). Increase in the proportion of linoleic acid 2

Ciência Rural, v.47, n.10, 2017. 
Table 3 - Regression equations of the effects of net energy levels in the adipose tissue (ADT) and Longissimus dorsi muscle (LDM).

\begin{tabular}{|c|c|c|c|c|}
\hline \multirow[b]{3}{*}{ C14:0 (Myristic acid) } & \multicolumn{2}{|c|}{ 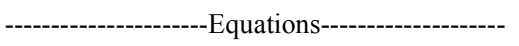 } & \multicolumn{2}{|c|}{ 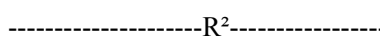 } \\
\hline & Adipose tissue & Muscle & ADT & LDM \\
\hline & $1.9638-0.0003 x$ & - & 0.86 & - \\
\hline C16:0 (Palmitic acid) & $35.493-0.0047 x$ & - & 0.74 & - \\
\hline C16:1 (Palmitoleic acid) & $4.1443-0.0009 x$ & $5.467-0.0009 x$ & 0.98 & 0.88 \\
\hline C18:0 (Stearic acid) & $15.993-0.0021 x$ & $17.996-0.0025 x$ & 0.46 & 0.99 \\
\hline C18:1n9 (Oleic acid) & $57.616-0.0071 x$ & $52.326-0.0035 x$ & 0.91 & 0.46 \\
\hline C18:2n6 (Linoleic acid) & $-16.282+0.0137 x$ & $-3.9228+0.0061 x$ & 0.97 & 0.68 \\
\hline C18:3n6( $\gamma$-Linolenic acid $)$ & $0.289-0.00006 x$ & $0.3242-0.00008 x$ & 0.84 & 0.91 \\
\hline C18:3n3 ( $\alpha$-Linolenic acid) & $-2.489+0.0013 x$ & $-0.9668+0.0006 x$ & 0.99 & 0.95 \\
\hline C20:4n6 (Arachidonic acid) & - & $-0.0981+0.00006 x$ & - & 0.92 \\
\hline C20:3n3 (Eicosatrienoic acid) & $-0.1146+0.00009 x$ & - & 0.93 & - \\
\hline Saturated fatty acids & $57.385-0.0081 x$ & $50.048-0.004 x$ & 0.79 & 0.90 \\
\hline Unsaturated fatty acids & $43.656+0.0076 x$ & $49.952+0.004 x$ & 0.72 & 0.90 \\
\hline Monounsaturated fatty acids & $64.445-0.0085 x$ & $55.965-0.0033 x$ & 0.92 & 0.34 \\
\hline Polyunsaturated fatty acids & $-19.727+0.0157 x$ & $-4.0022+0.0065 x$ & 0.97 & 0.67 \\
\hline Atherogenic index & $0.8194-0.00001 x$ & - & 0.74 & - \\
\hline Thrombogenic index & $2.0067-0.0003 x$ & - & 0.69 & - \\
\hline Omega 6: omega 3 & $45.023-0.0106 x$ & $53.516-0.0124 x$ & 0.93 & 0.86 \\
\hline
\end{tabular}

deposition was similar in both tissues, with 53 and $44 \%$ for adipose tissue and muscle, respectively.

The fatty acid $\alpha$-linolenic acid also presented a change, with 117 and 105\% increase in adipose tissue and muscle; respectively, due to the high concentration of this fatty acid in soybean oil. This fatty acid could adversely affect the organoleptic characteristics of meat when achieve at levels above 3\%, owing to its strong odor, which influence negatively the taste of meat (WOOD et al., 2003). Maximum levels obtained for this fatty acid in this study were 1.31 and $0.66 \%$ for the adipose tissue and muscle respectively.

The other fatty acids evaluated, namely palmitic, stearic and oleic acid are reported in high concentrations in soybean oil (ZAMBIAZI et al., 2007). However, their concentrations were low in fatty acid profiles recorded in this study. It should be considered that fatty acids are deposited as a result of the novo synthesis of other substrates in diets free or with low level of soybean oil. These synthesized fatty acids are saturated and monounsaturated with double bond in position 9. Larger quantities of certain fatty acids are deposited from an exogenous origin (which comes from the diet) when compared to the endogenous origin (DURAN-MONTGÉ et al., 2010).

Furthermore, the inclusion of lipids in the diet reduces the "new" synthesis of fatty acids and the essential fatty acids deposition rate decreases as the establishment of the diet increases (DURANMONTGÉ et al., 2010). In addition, high concentrations of linoleic acid in the diet may reduce the expression of stearoyl-CoA desaturase in the adipose tissue, reducing the formation and deposition of the fatty acid oleic (KOUBA et al., 2003). In turn, the other SFA and MUFA, which are not supplemented in the diet, had a reduced endogenous production in this study, which resulted in its decreased concentration in fat.

The consumption of the fatty acid palmitic have been associated with an increase in cardiovascular diseases (HUNTER et al., 2010). Reduction in the concentration of this fatty acid by 11.28 and $3.31 \%$ in adipose tissue and muscle; respectively, when increasing the NE from 2,300 to $2,800 \mathrm{Kcal} \mathrm{kg}^{-1}$ with the inclusion of soybean oil, results in improved quality of the final product for the consumer market.

There was an increase in all other PUFA, except for $\gamma$-linolenic, eicosapentaenoic and docosahexaenoic acid, in both adipose tissue and muscle. All these fatty acids can be derived from the diet, or in this case from the elongation and desaturation process from their substrates (linoleic and $\alpha$-linolenic acid). Therefore, as the amounts of these fatty acids increase in the diet, their concentrations in tissues are expected to increase (PÉREZ-PALACIOS et al., 2009). The reduction of $\gamma$-linolenic acid occurred possibly due to the competitive inhibition between the enzymes 
involved in the elongation and desaturation process of linoleic and $\alpha$-linolenic acid and formation of new fatty acids, affecting their production (RAES et al., 2004). Increasing net energy in the diets (GONÇALVES et al., 2015) decreased daily feed intake and even though there was no increase in daily net energy intake, the increase of soybean oil inclusion was enough to raise the concentration of PUFA. The PUFA increased by 53 and $42 \%$ in adipose tissue and muscle, respectively. Linoleic acid has a greater impact on PUFA and presents the highest concentration in this category. In addition, $\alpha$-linolenic acid showed a considerable increase in both tissues, following the increase in the NE in the diet by including soybean oil. The PUFA in adipose tissue went from 16.28 to $24.97 \%$, from the lowest to the highest level of energy. The respective increases of 6.75 and $3.73 \%$ in UFA in adipose tissue and muscle were not higher, since there was a reduction of $10.07 \%$ (adipose tissue) and $5.56 \%$ (muscle) in the MUFA, which also corresponds to UFA.

Ingestion of SFA is associated with an increased risk of coronary heart disease (BHUPATHIRAJU \& TUCKER, 2011). Replacement of SFA by PUFA could prevent the incidence of such diseases (JAKOBSEN et al., 2009). Therefore, a diet with high level of soybean oil that causes a reduction of SFA and MUFA, and increased PUFA, provides meat with better quality and healthier fat for the consumer. This is confirmed by the reduction in the atherogenic and thrombogenic indexes. The decrease in fatty acids increases such indexes, as seen for myristic, palmitic and stearic acid, which increases the UFA. This resulted in lower values than those established for foods intended for human consumption, as AI and TI values recorded for adipose tissue and muscle were, respectively, 0.41 and 1.00 , and 0.51 and 1.24 , while the mean values recorded in the literature were 0.60 and 1.37 (ULBRICHT \& SOUTHGATE, 1991).

The total daily intake values of $n 6: n 3$ recommended for human consumption must be lower than 4.00 (SCOLLAN et al., 2006). In this study, these values in the fat of the animals were higher than 4.00, regardless of the diet they consumed. This ratio is probably high due to the lower $\alpha$-linolenic acid values recorded in this study compared to the values of 1.32 and $0.66 \%$ of fat for adipose tissue and muscle reported in the literature (KOUBA et al., 2003). Despite these high values, adding soybean oil, that contains large amounts of linoleic acid, resulted in a decrease in the ratios from 21.13 to 15.86 and from 25.05 to 19.62 in adipose tissue and muscle, respectively. Including soybean oil in the diet improved the ratio and; therefore, this is considered an important factor to improve the quality of meat used for human consumption. Although, the ratio is not within the optimal range, supplementation with other foods can be performed to achieve it.

Further, it is possible to observe that with increasing levels of energy due to the addition of soybean oil, there was a lower efficiency in incorporating dietary fatty acids in muscle, than in adipose tissue (Table 3). From the equations, it is possible to observe that the larger magnitude caused by an increased NE in variables for adipose tissue when compared to variables from muscle, with the exception of stearic acid and n6:n3. Such results may be positively related to the different composition among types of fat, as $90 \%$ of adipose tissue are triglycerides, while in the muscle, there is a proportion of phospholipids, these being polar lipids and cell membrane constituents that remains constant (WOOD et al., 2008).

\section{CONCLUSION}

Increased level of net energy of the diet, using soybean oil, reduces the AI, TI, and n6:n3, while it increases the concentration of PUFA in the lipid profile of adipose tissue and muscle of pigs, with an increase of the fatty acids linoleic and $\alpha$-linolenic acid.

\section{BIOETHICS AND BIOSSECURITY COMMITTEE APPROVAL}

All procedures involving animals were approved by the Ethics Committee for the Use of Animals of Universidade Federal do Mato Grosso do Sul, under protocol no 429/2012.

\section{ACKNOWLEDGMENTS}

The support of Fundação de Apoio ao Desenvolvimento do Ensino , Ciência e Tecnologia do Estado de Mato Grosso do Sul (FUNDECT) for the scholarship granted through the "Call FUNDECT/CAPES No 02/2014 - Master's degree in Mato Grosso do Sul".

\section{REFERENCES}

AVERETTE GATLIN, L. et al. The effects of dietary fat sources, levels, and feeding intervals on pork fatty acid composition. Journal of Animal Science, v.80, p.1606-1615, 2002. Available from: $<$ https:// www.animalsciencepublications.org/publications/jas/articles/80/6/16 06>. Accessed: Sept. 02, 2016. doi: 10.2527/2002.8061606x.

BHUPATHIRAJU, S.N.; TUCKER, K.L. Coronary heart disease prevention: nutrients, foods, and dietary patterns. Clinica Chimica Acta, v.412, p.1493-1514, 2011. Available from: <http://dx.doi. org/10.1016/j.cca.2011.04.038>. Accessed: Sept. 20, 2016. doi: 10.1016/j.cca.2011.04.038.

DURAN-MONTGÉ, P. et al. De novo fatty acid synthesis and balance of fatty acids of pigs fed different fat sources. Livestock Science, 
v.132, p.157-164, 2010. Available from: <http://dx.doi.org/10.1016/j. livsci.2010.05.017>. Accessed: Jan. 15, 2017. doi: 10.1016/j. livsci.2010.05.017.

GONCCALVES, L.M.P. et al. Net energy levels for finishing barrows. Ciência Rural, v.45, p.464-469, 2015. Available from: $<$ http://dx.doi. org/10.1590/0103-8478cr20131573>. Accessed: May 23, 2017. doi: 10.1590/0103-8478cr20131573.

HARA, A.; RADIN, N.S. Lipid extraction of tissues with lowtoxicity solvent. Analytical Biochemistry, v.90, p.420-426, 1978 Available from: <http://dx.doi.org/10.1016/0003-2697(78)900465>. Accessed: Dec. 13, 2016. doi: 10.1016/0003-2697(78)90046-5.

HUNTER, J.E. et al. Cardiovascular disease risk of dietary stearic acid compared with trans, other saturated, and unsaturated fatty acids: a systematic review. American Journal of Clinical Nutrition, v.91, p.4663, 2010. Available from: <http://ajcn.nutrition.org/content/91/1/46. long $>$. Accessed: Oct. 29, 2016. doi: 10.3945/ajcn.2009.27661.

JAKOBSEN, M.U. et al. Major types of dietary fat and risk of coronary heart disease: a pooled analysis of 11 cohort studies. American Journal of Clinical Nutrition, v.89, p.1425-1432, 2009. Available from: <http://ajcn.nutrition.org/content/89/5/1425.long> Accessed: Feb. 07, 2017. doi: 10.3945/ajcn.2008.27124.

KIM, J.S. et al. Impact of dietary fat sources and feeding level on adipose tissue fatty acids composition and lipid metabolism related gene expression in finisher pigs. Animal Feed Science and Technology, v.196, p.60-67, 2014. Available from: <http://dx.doi. org/10.1016/j.anifeedsci.2014.06.007>. Accessed: Feb. 01, 2017. doi: 10.1016/j.anifeedsci.2014.06.007.

KOUBA, M. et al. Effect of a high linolenic acid diet on lipogenic enzyme activities, fatty acid composition, and meat quality in the growing pig. Journal of Animal Science, v.81, p.1967-1979, 2003. Available from: $<$ https://dl.sciencesocieties.org/publications/jas/abstrac ts/81/8/0811967?access $=0 \& v i e w=p d f>$. Accessed: Dec. 14, 2016. doi: $10.2527 / 2003.8181967 \mathrm{x}$

KOUBA, M.; MOUROT, J. A review of nutritional effects on fat composition of animal products with special emphasis on $\mathrm{n}-3$ polyunsaturated fatty acids. Biochimie, v.93, p.13-17, 2011. Available from: <http://dx.doi.org/10.1016/j.biochi.2010.02.027>. Accessed: Nov. 27, 2016. doi: 10.1016/j.biochi.2010.02.027.

NOBLET, J. Net energy evaluation of feeds and determination of net energy requirements for pigs. Revista Brasileira de Zootecnia, v.36, supl., p.277-284, 2007. Available from: <http://dx.doi.org/10.1590/ S1516-35982007001000025> . Accessed: Oct. 22, 2016. doi: 10.1590/ S1516-35982007001000025.

PÉREZ-PALACIOS, T. et al. Subcutaneous and intramuscular lipid traits as tools for classifying Iberian pigs as a function of their feeding background. Meat Science, v.81, p.632-640, 2009. Available from: $<$ http://dx.doi.org/10.1016/j.meatsci.2008.10.022>. Accessed: Nov. 20, 2016. doi: 10.1016/j.meatsci.2008.10.022

RAES, K. et al. Effect of dietary fatty acids on incorporation of long chain polyunsaturated fatty acids and conjugated linoleic acid in lamb, beef and pork meat: a review. Animal Feed Science and Technology, v.113, p.199-221, 2004. Available from: <http:// dx.doi.org/10.1016/j.anifeedsci.2003.09.001>. Accessed: Feb. 03, 2017. doi: 10.1016/j.anifeedsci.2003.09.001

ROSTAGNO, H.S. et al. Brazilian tables for poultry and swine: composition of feedstuffs and nutritional requirements. 3.ed. Viçosa: UFV. 2011. 252p.

SCOLLAN, N.D. et al. Innovations in beef production systems that enhance the nutritional and health value of beef lipids and their relationship with meat quality. Meat Science, v.74, p.17-33, 2006. Available from: <http://dx.doi.org/10.1016/j. meatsci.2006.05.002>. Accessed: Dec. 01, 2016. doi: 10.1016/j. meatsci.2006.05.002.

ULBRICHT, T.L.V.; SOUTHGATE, D.A.T. Coronary heart disease: Seven dietary factors. Lancet, v.338, p.985-992, 1991. Available from: $<$ http://dx.doi.org/10.1016/0140-6736(91)91846-M>. Accessed: Aug. 28, 2016. doi: 10.1016/0140-6736(91)91846-M.

WOOD, J.D. et al. Effects of fatty acids on meat quality: a review. Meat Science, v.66, p.21-32, 2003. Available from: $<\mathrm{http}: / / \mathrm{dx}$.doi. org/10.1016/S0309-1740(03)00022-6>. Accessed: Oct. 22, 2016. doi: 10.1016/S0309-1740(03)00022-6.

WOOD, J.D. et al. Fat deposition, fatty acid composition and meat quality: a review. Meat Science, v.78, p.343-358, 2008. Available from: $<$ http://dx.doi.org/10.1016/j.meatsci.2007.07.019>. Accessed: Jan. 16, 2017. doi: 10.1016/j.meatsci.2007.07.019.

ZAMBIAZI, R.C. et al. Fatty acid composition of vegetable oils and fats. Boletim do Centro de Pesquisa de Processamento de Alimentos, v.25, p.111-120, 2007. Available from: $<\mathrm{http}: / / \mathrm{dx}$.doi. org/10.5380/cep.v25i1.8399>. Accessed: Nov. 30, 2016. doi: 10.5380/cep.v25i1.8399. 